\title{
EFFECT OF EPIDERMAL GROWTH FACTOR ON IN VITRO PRODUCTION OF CAMEL (CAMELUS DROMEDARIUS) EMBRYOS BY USING FROZEN SEMEN
}

\author{
A. El-Sayed ${ }^{1}$,Hend A. Sayed ${ }^{2}$, E.E. El-Hassanein ${ }^{2}$, H. Murad ${ }^{1}$ and A.H. Barkawi ${ }^{1}$ \\ 1- Animal Production Department, Faculty of Agriculture, Cairo University, 12613 Giza, Egypt, 2- \\ Desert Research Center, Ministry of Agriculture and Land Reclamation, Mataria, Egypt
}

\section{SUMMARY}

The present study was conducted on 1640 oocytes of camels to investigate the effect of supplementing culture medium (TCM-199) with epidermal growth factor (EGF) on the competence of oocytes to mature and develop in vitro using frozen semen and to study the effect of season on recovery rate and quality of recovered oocytes. Oocytes were collected during breeding $(n=883)$ and nonbreeding $(n=757)$ seasons from she camels' ovaries $(n=191)$ delivered in normal saline solution at $37^{\circ} \mathrm{C}$ from a local slaughterhouse. Cumulus oocytes complexes (COCs) were recovered from ovaries by slicing technique. Good-quality oocytes were selected for in vitro maturation (IVM) in TCM-199 medium. Number of 206 COCs was inseminated with thawed semen $\left(3 \times 10^{6}\right.$ spermatozoa/ml). Culture process was conducted at $38.5^{\circ} \mathrm{C}$ in humidified air containing $5 \% \mathrm{CO}_{2}$.

The oocytes' maturation rate in medium contained EGF (81.19\%) was higher $(P<0.05)$ compared to control group (68.04\%). Cleavage rate, and percentages of obtained morula and early blastocyst were slightly higher when EGF was added to the maturation medium compared to control group.

In conclusion, camel frozen semen could be used successfully for in vitro production of camels embryos. In addition, EGF could improve camel oocytes maturation and cleavage rates.

Keywords: camels, IVM, EGF, season, cleavage rate

\section{INTRODUCTION}

Camels play a considerable role in agricultural matrix particularly in desert areas, providing milk, meat and transport (Skidmore, 2005). In Egypt, camels have a growth role particularly in meat production sector (Farah and Fischer, 2004). Reproductive efficiency of camels under natural pastoral conditions was reported to be low due to the short breeding season, late age of sexual maturity and long calving interval (El-Wishy, 1987 and Marai et al., 2009).

In Egypt, camels are displaying its maximum reproductive efficiency during the period from December to April (Basiouni, 2007), which affects with no doubt the capacity of embryo production (Amer and Moosa, 2009).

Applying in vitro embryo production technique may help in maximizing the gained embryos. However, there is still a lack of application of such technique in camels (Skidmore, 2005). Many trails were conducted to study the possibility of success of in vitro oocyte maturation in camelids and dromedary (Abdoon, 2001; Torner et al., 2003; Khatir et al., 2004; Nowshari and Wani, 2005; Khatir and Anouassi, 2006) indicating that preparation of semen and culture media are restricting the success on in vitro embryo production.
Addition of epidermal growth factor (EGF) to maturation media of camel oocytes was found to improve maturation rate (Khatir et al., 2004; Kafi et. al., 2005 and Wani and Wernery, 2010), which agrees with the obtained results on bovine (Lonergan et al., 1996; Park et al., 1997 and Lee et al., 2005).

Previous works aimed at reaching an appropriate protocol for in vitro camels' embryo production. Results indicated success rate of reaching to blastocyst stage from 14 to 23\% (Khatir and Anouassi, 2006; Abdoon et al., 2007; and Wani, 2009).

Semen preparation is one of the corner stone's on in vitro embryo production in camels. Different methods were used to separate good motile sperm to be used in in vitro fertilization step (Suthar and Shah, 2009). Fresh ejaculated spermatozoa have been used for IVF of dromedary oocytes with blastocyst rate up to 23\% (Khatir et al., 2004 and 2005), reduced to $17 \%$ when epididymal spermatozoa were used after storing in tris extender (Nowshari and Wani, 2005). Up to the knowledge of the authors rare data are available to describe the success rate of camel's embryo production using frozen semen.

The present study aimed at investigating the effect of epidermal growth factor on in vitro production of dromedary camels' embryos using frozen semen. In addition to 
study the season effect on recovery rate and quality of recovered oocytes.

\section{MATERIALS AND METHODS}

\section{Chemicals and media:}

Unless otherwise mentioned, all the chemicals, reagents, media, biologics and media constituents were purchased from Sigma-Aldrich Chemicals, Germany. Media and reagents were prepared under standard protocol following aseptic technique (Parrish et al., 1988). All incubation steps were conducted in $\mathrm{CO}_{2}$ incubator $\left(\begin{array}{lll}5 \% & \mathrm{CO}_{2}\end{array}\right)$ at $38.5 \%$.

\section{In vitro maturation of oocytes:}

A total number of 191 she camels' ovaries (Camelus dromedarius) were collected from slaughterhouse at El-Warak- Giza, Egypt and transported to the laboratory (Faculty of Agriculture Research Park, Cairo University, Giza) in a thermo flask containing warm physiological saline $\left(35\right.$ to $37^{\circ} \mathrm{C}, 0.9 \%$ sodium chloride solution, w/v), supplemented with 50 $\mu \mathrm{g} / \mathrm{ml}$ gentamicin within three to four $\mathrm{h}$. post slaughter. Ovaries were rinsed three times in saline at $35^{\circ} \mathrm{C}$ and attached tissues were removed using a sterile scissors. Thereafter, ovaries were washed with ethanol $(70 \%)$ to remove any contamination on the surface of the ovaries before placing in glass gars containing warm physiological saline ( 37 to 38 ${ }^{\circ} \mathrm{C}$ ) and kept in a water bath adjusted to $37{ }^{\circ} \mathrm{C}$ according (Khatir and Anouassi, 2006).

A total number of 1640 oocytes were collected all over the year as 883 during the breeding season (BS, from January to April) and 757 during non-breeding season (NBS, May to September). Cumuls oocytes complex (COCs) were harvested by slicing ovaries in warm $\left(37^{\circ} \mathrm{C}\right)$ phosphate buffered saline (PBS) supplemented with $50 \mu \mathrm{g} / \mathrm{ml}$ gentamicin (Torner et al., 2003). The retrieved containing COCs fluid was left for five minutes; the sediment was then transferred to a $60 \mathrm{~mm}$ petri dish (Greiner bio-one, Frickenhausen, Germany) and diluted with PBS and examined under a sterio-microscope (Leica Microsystems, MZ6, Wetzlar, Germany) to pick out COCs. Collected oocytes were evaluated and classified as good-quality and degenerated oocytes according to the criteria described by Wani (2009) and Khatir et al. (2007). Good oocytes, which characterized with more than one layer of homogeneous cumulus cells and dark cytoplasm were selected for in vitro maturation process. Oocytes were matured in tissue culture medium-199(TCM- 199) supplemented with $10 \%(\mathrm{v} / \mathrm{v})$ heat-treated $\left(56^{\circ} \mathrm{C}\right.$ for $\left.30 \mathrm{~min}\right)$ fetal bovine serum (FBS), $1 \mu \mathrm{g} / \mathrm{ml} \mathrm{FSH,} 1 \mu \mathrm{g} / \mathrm{ml}$ estradiol $17 \beta\left(E_{2}\right)$ and $50 \mu \mathrm{g} / \mathrm{ml}$ gentamicin (control medium). The medium was sterilized using $0.22 \mu \mathrm{m}$ millipore syringe filters and before incubation for at least two hours (Amer and Moosa, 2008). COCs were washed twice in warm PBS supplemented with $50 \mu \mathrm{g} / \mathrm{ml}$ Gentamicin and once in maturation medium; before culturing for maturation.

Two media were tested: the first was the control medium and the second was the control medium supplemented with $10 \mathrm{ng} / \mathrm{ml}$ EGF (treated medium). Oocytes were cultured in group $(10-15$ oocytes $)$ in a $100 \mu$ drop of maturation medium in a $35 \mathrm{~mm}$ petri dish, covered with mineral oil and cultured in incubator for $30 \mathrm{~h}$. Cumulus expansion (the main criterion of oocyte maturation) was examined under a stereomicroscope after the incubation period. Percentage of oocytes with expanded cumulus was recorded and based on the criteria of Amer and Moosa (2009).

\section{In vitro fertilization:}

Frozen semen was obtained from Reproduction Center, Desert Research Center, King-Marriott, Alexandria, Egypt to be used in this study. Two straws $(0.5 \mathrm{ml}$ each $)$ were thawed in a water bath, $38.5^{\circ} \mathrm{C}$ for 30 to $40 \mathrm{sec}$ (Skidmore, 2005). The straw was wiped with $70 \%$ ethyl alcohol before being opened. The contents of the straw were layered under five $\mathrm{ml}$ washing sperm medium, (TCM-199 medium supplemented with four $\mathrm{mM}$ caffeine sodium benzoate; $\mathrm{pH} 7.5$, filtered using 0.22 $\mu \mathrm{m}$ syringe filter) and centrifuged twice for five min at $1500 \mathrm{rpm}$ at 32 to $35^{\circ} \mathrm{C}$. Sperm pellet was mixed with appropriate volume (two $\mathrm{ml}$ ) of pre-warmed and pre-filtered fertilization medium as described by Park et al. (1997). The final sperm concentration was adjusted to $3 \times 10^{6} / \mathrm{ml}$. Four drops of a $100 \mu \mathrm{l}$ sperm suspension were placed in a $35 \mathrm{~mm}$ petri dish and covered with a pre-warmed mineral oil. Matured oocytes were washed three times in fertilization medium. Ten to fifteen oocytes were placed into each of the sperm drops and cultured in $\mathrm{CO}_{2}$ incubator for $18 \mathrm{~h}$ (Khatir et al., 2007). Presumptive zygotes were washed twice in a developmental medium (TCM-199 supplemented with $1 \%$ FBS, $12.5 \mu \mathrm{l} / \mathrm{ml}$ sodium pyruvate and L-glutamine $25 \mu \mathrm{l} / \mathrm{ml}$, pH 7.2). About 10 to 15 of presumptive zygotes were cultured in $100 \mu \mathrm{l}$ drop of developmental medium covered with mineral oil and incubated for eight days. Medium was renewed every two days during the incubation process.

\section{Statistical analysis:}

The obtained data of recovery rate were statistically analyzed by T- test using SPSS 19 
(2001) and that of IVM and IVF were analyzed by Cochran's Q test using XLSTAT (2012). This method compares several related samples and can be used as a non-parametric alternative to the two way ANOVA.

\section{RESULTS}

Effect of season on oocytes' recovery rate and quality:

Recovery rate:

Number of oocytes recovered per ovary during breeding and non-breeding seasons did not differed significantly, however was higher in non- breeding season compared to breeding one by about $20 \%$. Moreover, percentage of accepted oocytes per ovary was higher by $8.8 \%$ in breeding season relative to the nonbreeding one (Table 1).

\section{Effect of Medium:}

\section{In vitro maturation and fertilization rates:}

Adding EGF to maturation medium (G2) improved $(\mathrm{P}<0.05)$ the maturation rate by approximately $13.5 \%$ relative to the control group (G1). Fertilization rate also was higher by about $2.7 \%$ in $\mathrm{G} 2$ relative to $\mathrm{G} 1$ (Table 2).

\section{Embryonic development:}

Developmental stages of embryo are shown in plate (1) (a, b, c, d, e, f and g). The cleavage rate, morula and early blastocyst was higher $(\mathrm{P}<0.05)$ in embryos of $\mathrm{G} 2$ than of G1. In G2 percentages of the cleaved embryos increased by about $10 \%$ than in $\mathrm{G} 1$ for 2-32 cell stage, $11.4 \%$ for morulla stage and $2.86 \%$ for early blastocyst stage (Table 3).

\section{DISCUSSION}

The non-significant increase in recovery rate during non-breeding season in the dromedary camel may be due to cessation of ovulation during this season. This result is in contrary with the results of Abdoon (2001) which reported the yield and quality of oocytes in camel were higher during the breeding season. On the other hand, high percentage $(90.8 \%)$ of recovered good oocytes (Table 1) during breeding season is in accordance with the results of Amer and Moosa (2008).

Maturation rate of embryos cultured in TCM-199 medium (68\%,Table 1) is higher than to the results of Khatir et al. (2004) and less than that of Kafi et al. (2005) and Wani and Wernery (2010) (67-71\%). This difference may be due to the short time of incubation period applied in the present work $(30 \mathrm{~h})$ compared to the longer period applied in the previous works (36- $42 \mathrm{~h})$.

The obtained higher maturation rate in TCM-199 medium supplemented with EGF during culture process after fertilization (G2) compared to G1 is in accordance with that stated in buffaloes (Dinesh and Govind, 2010), Boer goat (Wang et al., 2007), bovine (Sirisathien and Brackett, 2003; Bastan et al., 2010) and sheep (Shabankareh and Zandi, 2010). These results may be due to the positive effect of EGF on nuclear and cytoplasmic maturation of cumulus enclosed oocytes in vitro (Lonergan et al., 1996 and Park et al., 1997). EGF in cultural medium enhances cleavage (Conti et al., 2005).

Comparable maturation rate obtained in the present results after $30 \mathrm{~h}$. incubation may conclude that the maturation time for dromedary camel oocytes could be $30 \mathrm{~h}$ in TCM 199 media supplemented with EGF, which is in consistence with studies of Khatir et al. (2004 \& 2005) on camel. The importance of determining the optimal in vitro oocyte maturation time is to avoid oocyte aging if in vivo insemination is delayed (Hunter, 1989) and subsequent poor development (Amer and Moosa, 2008).

In conclusion, the present results suggest that EGF might be one of the factors improved camels oocytes maturation, cleavage rate and proportion of blastocyst stage. Further detailed studies are required to compare between fresh and frozen semen on embryo development, in addition to test the effect of EGF on culture media.

\section{ACKNOWLEDGEMENT}

The authors are thankful to Dr. Khaled ElBahrawi, Reproduction Center, Desert Research Center, King-Marriott, Alexandria, Egypt for supplying with the frozen semen. The study was kindly funded by Academy of Scientific Research and Technology (ASRT), 101 Kasr El-Einy St., Cairo, Egypt.

\section{REFERENCES}

Abdoon, A.S.S., 2001. Factors affecting follicular population, oocyte yield and quality in camels (Camelus dromedarius) ovary with special reference to maturation time in vitro. Anim. Reprod. Sci., 66: 71-79.

Abdoon, A.S., O.M. Kandil, B. Berisha, H. Kliem, and D. Schams, 2007. Morphology of dromedary camel oocytes and their ability to spontaneous and chemical parthenogenetic activation. Reprod. Domest. Anim., 42: 88-93.

Amer, H. and A. Moosa, 2009. Effect of season and culture media on the competence of dromedary camel oocyte to mature in vitro. Global Veterinaria, 3(1): 01-08. 
Amer, H. and A. Moosa, 2008. Relationship between season of the year, culture medium and in vitro oocyte competence in dromedary camels. Bulg J. Vet. Med., 11(3): 195- 204.

Basiouni, G.F., 2007. Follicular wave pattern, folliculogenesis and assisted reproductive techniques in the non-pregnant female dromedary camel (Camelus dromedarius). J. Biol. Sci., 7(6): 1038- 1045.

Bastan, A., B. Polat, D. Bakiacar, Ö. Korkmaz, and A. Colak, 2010. Determination of optimal dose of EGF for bovine oocyte maturation and subsequent in vitro ertilization and culture in two media. Turk. J. Vet. Anim. Sci., 34(1): 33-38.

Conti, M., M. Hsieh, J.Y. Park, and Y.Q. Su, 2005. Role of the epidermal growth factor Network in ovarian follicles. Mol. Endocrinol., 20(4): 715-723.

Dinesh, K. and N.P. Govind, 2010. Effect of epidermal and insulin-like growth factor-1 on cumulus expansion, nuclear maturation and fertilization of buffalo cumulus oocyte complexes in simple serum free media DMEM and Ham's F-10. Eterinarski arhiv, 74 (1): 13-25.

El Wishy, A.B., 1987. Reproduction in the female dromedary (Camelus dromedarius): Anim. Reprod. Sci., 82: 587-593.

Farah, Z. and A. Fischer, 2004. The camel ( $C$. dromedarius) as a meat and milk animal: Handbook and product development. Vdf. Hochschulverlag. http://www.camelgate.com/.

Hunter, R.H., 1989. Aging of the unfertilised cow egg in vivo: How soon is fertility compromised? Vet. Record., 124, 489-490.

Kafi, M., F. Mesbah, H. Nili, and A. Khalili, 2005. Chronological and ultrastructural changes in camel (Camelus dromedarius) oocytes during in vitro maturation. Theriogenology, 63: 2458-2470.

Khatir, H., and A. Anouassi, 2006. The first dromedary (Camelus dromedarius) offspring obtained from in vitro matured, in vitro fertilized and in vitro cultured abattoir-derived oocytes. Theriogenology, 65: 1727- 1736.

Khatir, H., A. Anouassi, and A. Tibary, 2007. Effect of follicular size on in vitro developmental competence of oocytes and viability of embryos after transfer in the dromedary (Camelus dromedarius). Anim. Reprod. Sci., 99: 413- 420.

Khatir, H., A. Anouassi, and A. Tibary, 2005. In vitro and in vivo developmental competence of dromedary (Camelus dromedarius) embryos produced in vitro using two culture systems (mKSOMaa and oviductal cells). Reproduction in Domestic Animals , 40(3):245-249.

Khatir, H., A. Anouassi, and A. Tibary, 2004. Production of dromedary (Camelus dromedarius) embryos by IVM and IVF and co-culture with oviductal or granulosa cells. Theriogenology , 62: 1175-1185.

Lee, G.S., H.S. Kim , S.H. Hyun, H.Y. Jeon , D.H. Nam , Y.W. Jeong, S. Kim , J.H. Kim, S.K. Kang , B.C. Lee and W.S. Hwang, 2005. Effect of epidermal growth factor in preimplantation development of porcine cloned embryos. Molecular Reproduction and Development, 71(1):4551.

Lonergan, P., C. Carolan, A.V. Langendonckt, and I. Donnay, 1996. Role of epidermal growth factor in bovine oocyte maturation and preimplantation embryo development in vitro. Biol. Reprod., 54: 1420-1429.

Marai, I.F.M., A.E.B. Zeidan, A.M. AbdelSamee, A. Abizaid, and A. Fadiel, 2009. Camels reproductive and physiological performance traits as affected by environmental conditions. Tropical and Subtropical Agroecosystems, 10: 129-149.

Nowshari, M.A., and N.A. Wani, 2005. Camelid embryo development in vitro: effect of protein supplementation in maturation medium and subsequent culture in two different media on fertilization and development. Reprod. Fertil. Dev., 17: 276 (Abstract).

Park, K.W., K. Iga, and K. Niwa, 1997. Exposure of bovine oocytes to EGF during maturation allows them to develop to blastocysts in a chemically-defined medium. Theriogenology, 48(7): 11271135.

Parrish, J.J., J.L. Susko-Parrish, M.A. Winer, and N.L. First, 1988. Capacitation of bovine sperm by heparin. Biol. Reprod., 38: 1171-1180.

Shabankareh, H.K., and M. Zandi, 2010. Developmental potential of sheep oocytes cultured in different maturation media: effects of epidermal growth factor, insulinlike growth factor I, and cysteamine. Fertil. Steril., 94(1):335-340.

Sirisathien, S., and B.G. Brackett, 2003. TUNEL analyses of bovine blastocysts after culture with EGF and IGF-I. Mol. Reprod. Dev., 65(1):51-56.

Skidmore, J.A., 2005. Reproduction in dromedary camels: an update. Anim. Reprod., 2(3): 161-171.

SPSS Inc. (2001) SPSS 11.0 Advanced Models: Englewood Cliffs, NJ: Prentice Hall. 
Suthar, V.S., and R.G. Shah, 2009. Bovine in vitro embryo production: an overview. Vet. World, 2(12): 478- 479.

Torner, H., B. Heleil, H. Alm, I.M. Ghoneim, V. Srsen, W. Kanitz, A .Tuchscherer, and E.M. Fattouh, 2003. Changes in cumulusoocyte complexes of pregnant and nonpregnant camels (Camelus dromedarius) during maturation in vitro. Theriogenology, 60: 977-987.

Wang, Z.G., Z.R. Xu, and S.D Yu, 2007. Effects of oocytes collection techniques and maturation media on in vitro maturation and subsequent embryo development in Boar goat. Czech J. Anim. Sci., 52(1): 21-25.
Wani, N.A., 2009. In vitro embryo production in camel (Camelus dromedarius) from in vitro matured oocytes fertilized with epididymal spermatozoa stored at $4^{\circ} \mathrm{C}$. Anim. Reprod. Sci, 111(1): 69- 79.

Wani, N.A, and U. Wernery, 2010. In vitro maturation of dromedary (Camelus dromedarius) oocytes: effect of different protein supplementations and epidermal growth factor. Reproduction in Domestic Animals, 45(5):e189-193.

XLSTAT, 2012, statistical software for MS Excel- statistics and data analysis with MS Excel Addinsoft 224 centre street, $3{ }^{\text {rd }}$ floor New York, NY 10013 USA.

Table 1. Mean values (Mean \pm S.E.) of oocytes recovered from ovaries in breeding season (BS) and non-breeding season (NBS)

\begin{tabular}{lccc} 
Trait & BS & NBS & Overall \\
\hline No. of Ovaries & 112 & 79 & 191 \\
No. of collected oocytes & 883 & 757 & 1640 \\
Recovery rate (oocytes/ovary) & $8.6 \pm 0.8$ & $10.30 \pm 1.4$ & $9.4 \pm 0.8$ \\
No. of accepted oocytes /ovary & $7.7 \pm 0.7$ & $8.6 \pm 1.2$ & $8.1 \pm 0.7$ \\
Good oocytes (\%) & $(90.8 \%)$ & $(82.0 \%)$ & $(86.4 \%)$ \\
\hline
\end{tabular}

Table 2. Oocytes maturation (\%) in dromedary camel cultured in TCM-199 medium (G1) or in TCM-199 medium supplemented with epidermal growth factor (G2)

\begin{tabular}{lcc}
\hline Trait & G1 & G2 \\
\hline No. of oocytes & 654 & 654 \\
Matured oocytes $(\%)$ & 68.04 & $81.19^{*}$ \\
Fertilized ova $(\%)$ & 17.6 & 20.3 \\
\hline
\end{tabular}

Values differ significantly at $(P<0.05)$.

Table 3. In vitro development of camel embryos matured in TCM-199 medium (G1) or TCM-199 supplemented with EGF and fertilized with frozen semen

\begin{tabular}{ccccc}
\hline $\begin{array}{c}\text { Experimental } \\
\text { Groups }\end{array}$ & $\begin{array}{c}\text { No. of fertilized } \\
\text { oocytes }\end{array}$ & $\begin{array}{c}\mathbf{2 - 3 2} \text { cells } \\
\text { stage }\end{array}$ & $\begin{array}{c}\text { Morulla } \\
\text { Stage }\end{array}$ & $\begin{array}{c}\text { Early blastocyst } \\
\text { stage }\end{array}$ \\
\hline G1 & 105 & 9.52 & 6.67 & 0.95 \\
G2 & 105 & $19.05^{*}$ & $18.10^{*}$ & 3.81 \\
\hline
\end{tabular}

* Values differ significantly at $\mathrm{P}<0.05$. 


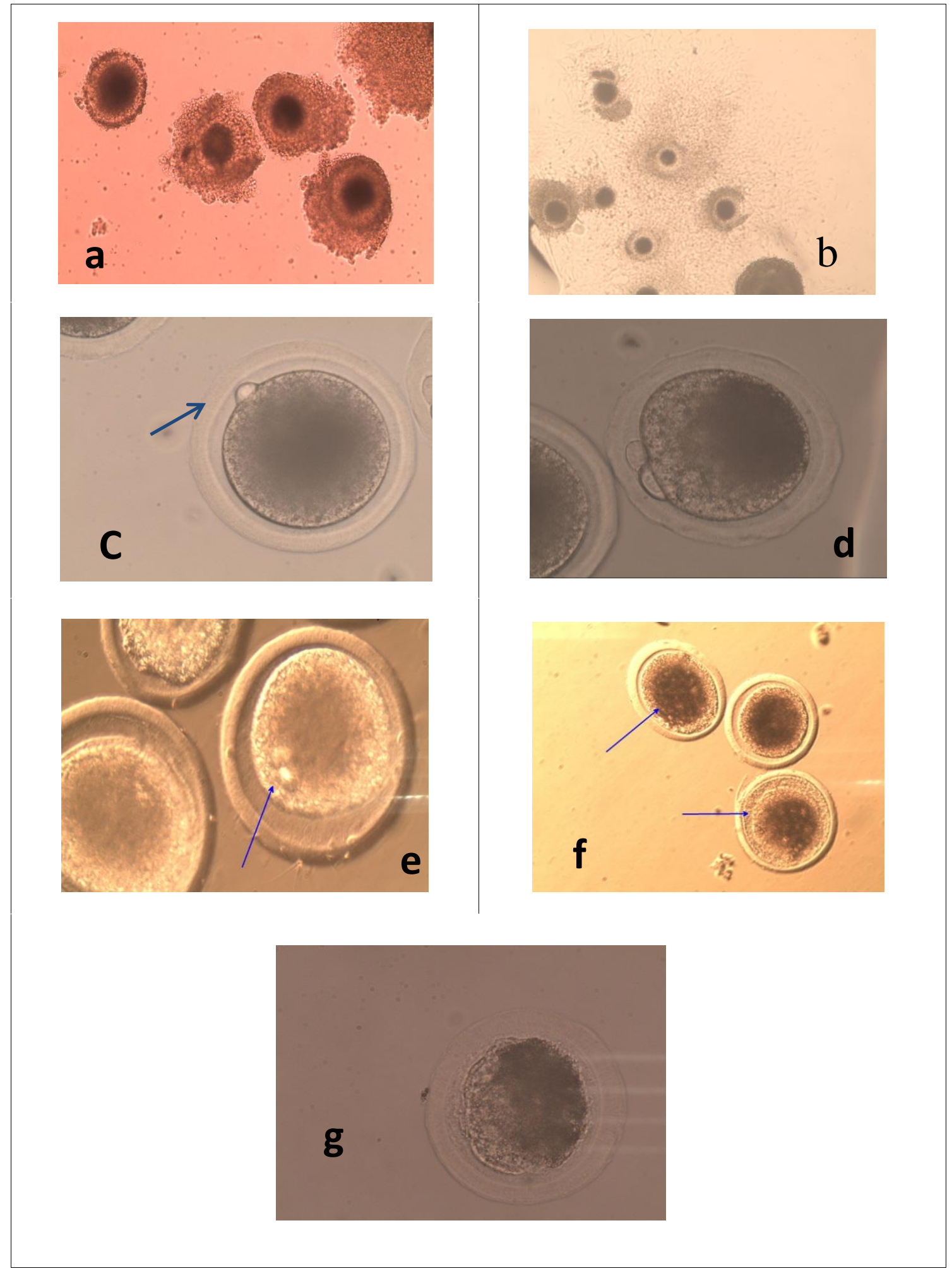

Plate.1. Developmental stages of in vitro produced embryos showing: a- immature oocytes with the condensed cumulus cells $100 \mathrm{X}$, b- matured oocytes with expanded cumulus cells 100X, cdenuded matured oocyte with $1^{\text {st }}$ polar body $200 \mathrm{X}$, d- matured oocyte extruded the $2^{\text {nd }}$ polar body 320X, e-fertilized oocyte with two pronuclei 400X, f- Morula 160X and g- early blastocyst 320X 
تأثير إضافة عامل نمو الجلد علي إنتاج أجنة الجمال معمليا بإستخدام السائل المنوي المجمد

أثرف السيد1، هند عبد الكريم سيد²، السيد السيد الحسانين، حمدي مراد1، أثرف هثام برقاوي1

1- قسم الإنتاج الحيواني، كلية الزراعة، جامعة القاهرة، 12613، الجبزة، مصر، 2- مركز بحوث الصحراء، وزارة النزراعة واستصلاح الاراضي، المطرية، مصر للنر

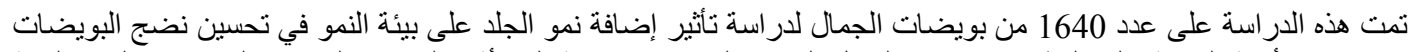

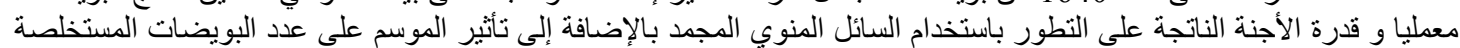
لكل مبيض وكذللك جودتها.

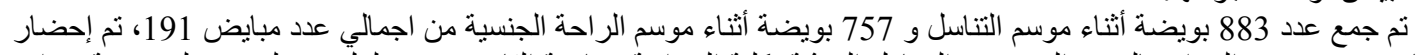
المبايض من مجزر الوراق بالجيزة إلى مجمع المعامل البحثية بكلية الزراعة بردة جامعة القاهرة في محلول فسيولوجي على على درجة حرارة

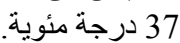

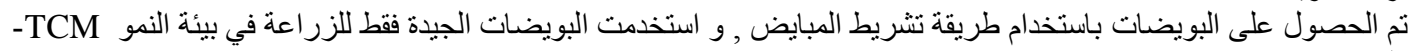
199 لمدة 30 ساعة.

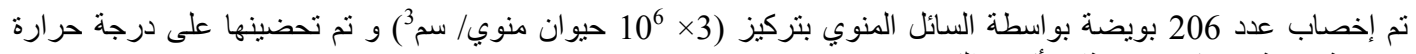
38.5

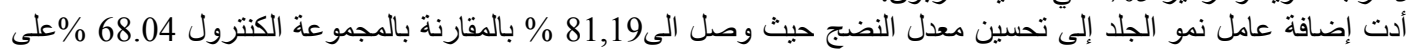

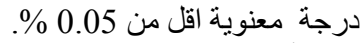
كذلك أدت إضافة عامل نمو الجلد الى تحسين نسبة الانقسام والموريو لا و كذلك البلاستوسيت بالمقارنة بمجموعة الكنترول إلا أن هذا



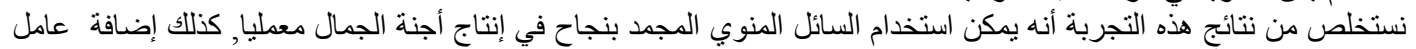

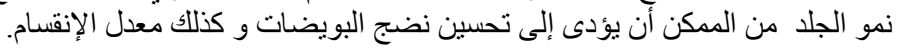

